\title{
Psychomotor conditions of bus drivers subjected to noise and vibration in the working environment
}

\author{
Anna Romańska-Zapała ${ }^{1}$, Alicja Kowalska-Koczwara ${ }^{2, *}$, Aleksander Korchut ${ }^{3}$ and Krzysztof \\ Stypuła $^{2}$ \\ ${ }^{1}$ Cracow University of Technology, Malopolska Laboratory of Efficient Building, 31-155 Kraków, \\ Warszawska 24 St., Poland \\ ${ }^{2}$ Cracow University of Technology, Institute of Structural Mechanics, 31-155 Kraków, Warszawska \\ 24 St., Poland \\ ${ }^{3}$ University of Social Sciences and Humanities, 40-326 Katowice, Technikow 9 St., Poland
}

\begin{abstract}
The influence of vibration on human body is an issue that from several decades is a subject of many research and experiments. But most of these research concern on negative influences on human body. The paper presents methodology and results of research conducted on bus drivers of National Urban Transport in Tychy. The study involved fourteen drivers. First stage of the experiment included biomechanical and medical tests. After that psychological tests were made determining such factors like personality characteristics and stress resistance. Second stage included monitoring of psychomotor condition of drivers during night and day shifts, before and after work.
\end{abstract}

\section{Introduction}

Bus drivers of the public transport have various physical factors in their workplace. The most significant influence on the driver's body have noise and vibrations, both hand-arm and whole body vibration [1]. These factors cause functional and physiological effects [2] [3] [4] [5]. Drivers are exposed to deterioration of their health and occurrence of occupational diseases [6].

Working as a bus driver is considered a high-risk group for the appearance of workrelated stress [7], this classifies it into professions that require special psychomotor skills. Drivers are required, on the one hand, to set specific ethical standards or skills for social functioning and, on the other hand, irreproachable mental health and specific psychological and cognitive traits.

\footnotetext{
* Corresponding author: akowalska@pk.edu.pl
} 
So, it is true that the driver largely determines the proper functioning of communication in both urban agglomerations and off-shore centers as well as has an influence on the safety in public transport [8]. Evidence of the importance of the occupation of the bus driver in public transport is the number of publications on this subject. At the same time, in Poland as well as in many European countries, a new field has been formed from applied psychology dealing exclusively with the driver's profession. This field is the transportation psychology. Its competencies include periodic driver examinations of response parameters, visual coordination, perceptual sensitivity and resistance to stress-generating situations.

Among the many factors of the drivers' working environment, that adversely influence driver's health and psychophysical efficiency, stress has a significant role [3]. Driving a bus under heavy traffic conditions (currently the norm) is a challenge at the present time [9]. The scope of driver's duties is differential. It forces the driver to perform several tasks simultaneously - observing the road and the inside of the vehicle, reacting to the changing road situation, maintaining the time regime. Simultaneous contact with the passengers and controlling the emotions accompanying with these activities lead in consequence to a state of permanent stress [10].

Many studies conducted on drivers (including bus drivers) describe the most common physiological changes accompanying with work. These are: high blood pressure and pulse rate, accelerated breathing with congestion, excessive sweating and muscle fatigue. The consequences of these changes are:

- diseases of the circulatory system including increased mortality

- bone diseases, mainly degeneration of the spine

- $\quad$ psychosomatic diseases (peptic ulcer disease)

- obesity

In addition to the costs associated with physical health, constant fatigue and forced position lead to disturbances in the nervous system and its functional representation [11]. This mainly concerns visual and motor coordination and cognitive functions, including attention deficit disorder. Constant tension of skeletal muscles (especially upper limbs) causes movements to become inaccurate. The effectiveness of motor activities decreases.

The nervous system often reacts in a defensive manner to the whole body. Nervous system previously fatigued than the rest of the system protects the entire body from exhaustion. It makes possible to maintain a functional reserve.

Additional disadvantages are external factors. They are excessive noise, vehicle vibration, exhaust emissions, poor visibility and unfavorable meteorological conditions.

It should be added, however, that bus drivers are a professional group subjected to periodic selection [12]. Workers with special psychophysical features are admitted to this type of work, characterized by easiness of adaptation to difficult working conditions.

This article presents the process and results of studies of bus drivers of the National Urban Transport in Tychy (Państwowa Komunikacja Miejska w Tychach).

\section{Purpose and methodology of research}

The aim of the study was to determine the influence of the working environment of city bus drivers working in a two-shift system on their cognitive and motor skills.

The study involved fourteen bus drivers employed in the National Urban Transport in Tychy. The criterion of inclusion in the experiment was the admission of the driver to work on the basis of valid periodic medical examinations and psychological tests as well as the dispatcher agreement. The tested drivers are only men aged 24 to 49 years. These studies were conducted in two ways.

The first stage of research was related to determining the working conditions of the bus driver. For this purpose, the driver's seat was subjected to vibration and measurements of 
whole body vibrations were made in accordance with existing regulations [13]. For the measurement, a four-channel sound and vibration SVAN 948 sensor, which is mounted on the driver's seat was used. The measurements were carried out during driving with passengers on urban and suburban roads. Research was performed during ride on a full bus route. In the conducted experiment, the measurements included drivers working in two shifts system on seven buses.

The second stage of the research concerned the cognitive and motor skills of the examined drivers. A computer-aided set of psychological tests of cognitive and motor skills was used for the research. The set consisted of a computer, keyboard and exposition monitor. It is a non-invasive method i.e. it does not directly affect the person's body. The study consisted of performing the commands and research tasks displayed on the monitor. The results of the research are two parameters: time of performance and the level of accuracy. The device identified, among others, time of motor response to task stimulus and number of correct and incorrect responses. On the basis of the obtained data it was possible to determine the current level of changes in the organism of a subject under the influence of a specific factor (stimulus). In the research following tests were used:

- $\quad$ Line Test

Efficiency test of perceptual vision (focus and selectivity of the image) and attention. The task of the investigated person was to enter on the keyboard the correct number of horizontal lines displayed on the monitor.

- Summary Test

Studying the speed and efficiency of memory-based operations, attention (dividing and concentrating), and perceptiveness.

The task is to execute in memory the operation of adding numbers displayed on the monitor and then typing the result on the keyboard.

- Memory Test

Research on the function of attention and memory task (operational memory).

The task is to execute in memory the operation of adding numbers displayed on the monitor and then, after some time, typing the result on the keyboard.

- Test of letters substitution

Visual-motor coordination and concentration on the task. In this task, the investigated person searched in the letter collection the assigned numbers from which he "constructed" the specified word.

Each of the tests consisted of three parallel test matrices based on difficult-to-remember simple task formulas. This limited the ability to learn text tasks in the next study. All measurements were performed under repetitive conditions. These measurements represent a pilot study.

\section{Results and discussions}

The results of vibration tests are compiled and summarized in Table 1. The type of bus, its mileage and age are given. The vibrations that influence the driver through the chair for each of the buses are shown in the last column of Table 1. 
Table 1. Summary of results for individual buses.

\begin{tabular}{|c|c|c|c|c|}
\hline 1 & Bus type & $\begin{array}{c}\text { Mileage } \\
{[\mathrm{km}]}\end{array}$ & $\begin{array}{c}\text { Age } \\
{[\text { months }]}\end{array}$ & $\begin{array}{c}\text { RMS } \\
{\left[\mathrm{m} / \mathrm{s}^{2}\right]}\end{array}$ \\
\hline 2 & not articulated & 26916 & 4 & 0.322 \\
\hline 3 & articulated & 456031 & 51 & 0.372 \\
\hline 4 & articulated & 4835 & 1 & 0.412 \\
\hline 5 & not articulated & 517855 & 107 & 0.349 \\
\hline 6 & not articulated & 415805 & 51 & 0.323 \\
\hline 7 & not articulated & 263022 & 51 & 0.383 \\
\hline
\end{tabular}

The obtained results show the highest weighted value of vibration acceleration in the $Z$ direction, which is the main vertical axis of the driver (along the spine). With regard to exposure to vibration at the workplace this limit level for 8 is equal $0.5 \mathrm{~m} / \mathrm{s}^{2}$ [13], exceeding the values stated in the regulation, the employer is obliged to take actions reducing the occupational risk.

There is a low dependence of the observed vibration acceleration on the mileage of the vehicle. In all vehicles, the driver's seat was characterized by high vibration damping ability. In the case of cognitive and motor efficiency tests, the examined drivers used a computeraided set of psychological tests examining cognitive and motor skills. The study consisted of performing the commands and research tasks displayed on the monitor. The results of the study were two parameters: time of performance and the level of correctness.

The device identified, among others, time of motor response to task stimulus, number of correct and incorrect responses. On the basis of the obtained data it was possible to determine the current level of changes in the organism of the subject under the influence of the stimulus. Measurements were made three times:

- First measurement on the second day of the experiment (morning group 2R and afternoon group 2P),

- Second measurement in the fourth day of the experiment (morning group 4R and an afternoon group 4P),

- Third measurement in the sixth day of the experiment (morning group 6R and an afternoon group 6P).

Only the execution times of individual test tasks were analyzed. Line Test results are presented in Figure 1, and the t-test for dependent samples are listed in Table 2. 
Table 2. Summary results for the Line Test.

\begin{tabular}{|c|c|c|c|c|c|c|}
\hline $\begin{array}{c}\text { Correlation } \\
\text { between } \\
\text { measurements }\end{array}$ & $\begin{array}{c}\text { Average } \\
\text { time to } \\
\text { complete } \\
\text { the task }\end{array}$ & $\begin{array}{c}\text { Standard } \\
\text { deviation }\end{array}$ & $\begin{array}{c}\text { Number } \\
\text { of } \\
\text { drivers }\end{array}$ & $\begin{array}{c}T \\
\text { student } \\
\text { value }\end{array}$ & $\begin{array}{c}\text { Degree } \\
\text { of } \\
\text { freedom }\end{array}$ & $\begin{array}{c}p \text { - level of } \\
\text { significance }\end{array}$ \\
\hline 1 and 2 & 23.53214 & 3.99235 & 14 & 4.07975 & 13 & 0.001302 \\
\hline 1 and 3 & 22.56429 & 6.31341 & 14 & 5.37759 & 13 & 0.000126 \\
\hline 2 and 3 & 22.56429 & 6.31341 & 14 & 0.77774 & 13 & 0.450648 \\
\hline
\end{tabular}

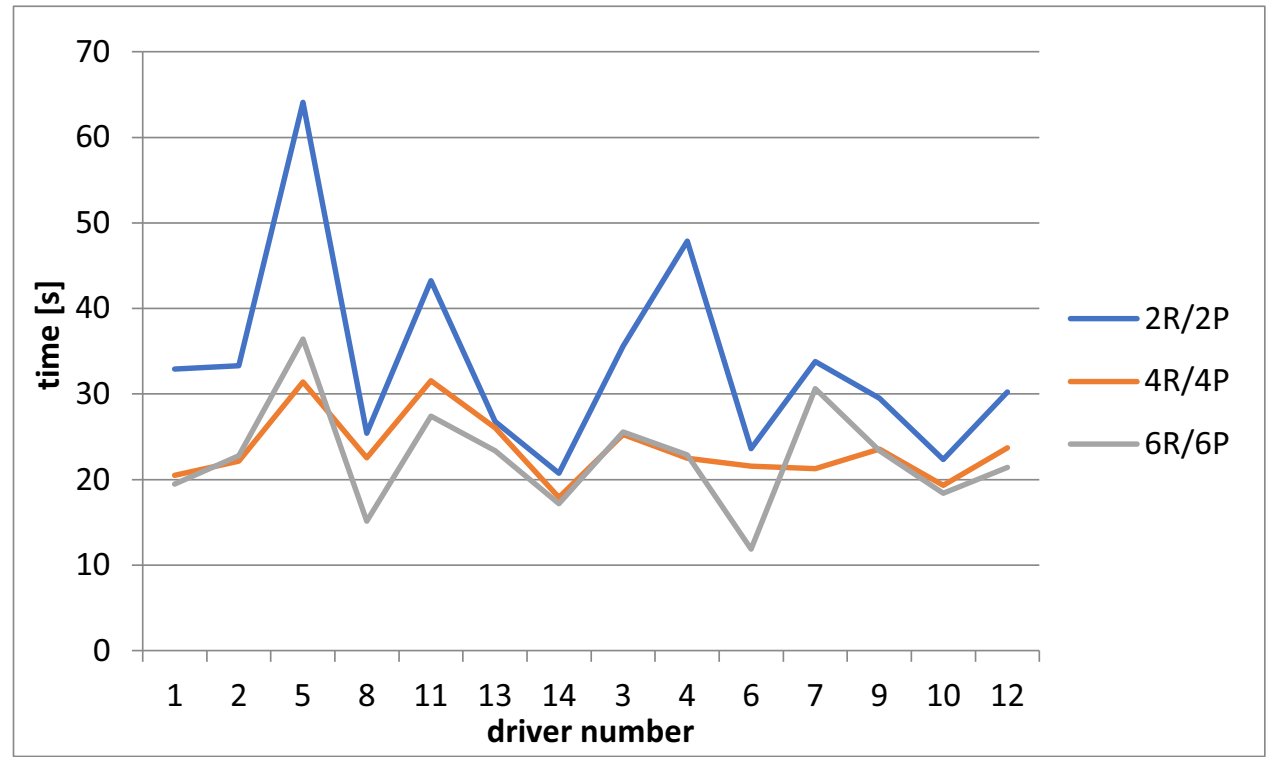

Fig. 1. Line Test results on the second $(2 \mathrm{R} / 2 \mathrm{P})$, fourth $(4 \mathrm{R} / 4 \mathrm{P})$ and sixth $(6 \mathrm{R} / 6 \mathrm{P})$ day of the morning and afternoon group experiment.

As can be seen from the above table, the duration of the test in the Line Test significantly decreases in the second study (compared to the first one) $p<0.01$, whereas in the third study the change compared to the second test is not statistically significant.

Summary Test

The results of the Summary Test are presented in Figure 2 and the test values for the dependent samples are listed in Table 3. 
Table 3. Summary results for the Summary Test.

\begin{tabular}{|c|c|c|c|c|c|c|}
\hline $\begin{array}{c}\text { Correlation } \\
\text { between } \\
\text { measurements }\end{array}$ & $\begin{array}{c}\text { Average } \\
\text { time to } \\
\text { complete } \\
\text { the task }\end{array}$ & $\begin{array}{c}\text { Standard } \\
\text { deviation }\end{array}$ & $\begin{array}{c}\text { Number } \\
\text { of } \\
\text { drivers }\end{array}$ & $\begin{array}{c}T \\
\text { student } \\
\text { value }\end{array}$ & $\begin{array}{c}\text { Degree of } \\
\text { freedom }\end{array}$ & $\begin{array}{c}p \text { - level of } \\
\text { significance }\end{array}$ \\
\hline 1 and 2 & 74.45071 & 15.05633 & 14 & 4.33991 & 13 & 0.000802 \\
\hline 1 and 3 & 64.09929 & 12.77247 & 14 & 7.59144 & 13 & 0.000004 \\
\hline 2 and 3 & 64.09929 & 12.77247 & 14 & 3.93807 & 13 & 0.001699 \\
\hline
\end{tabular}

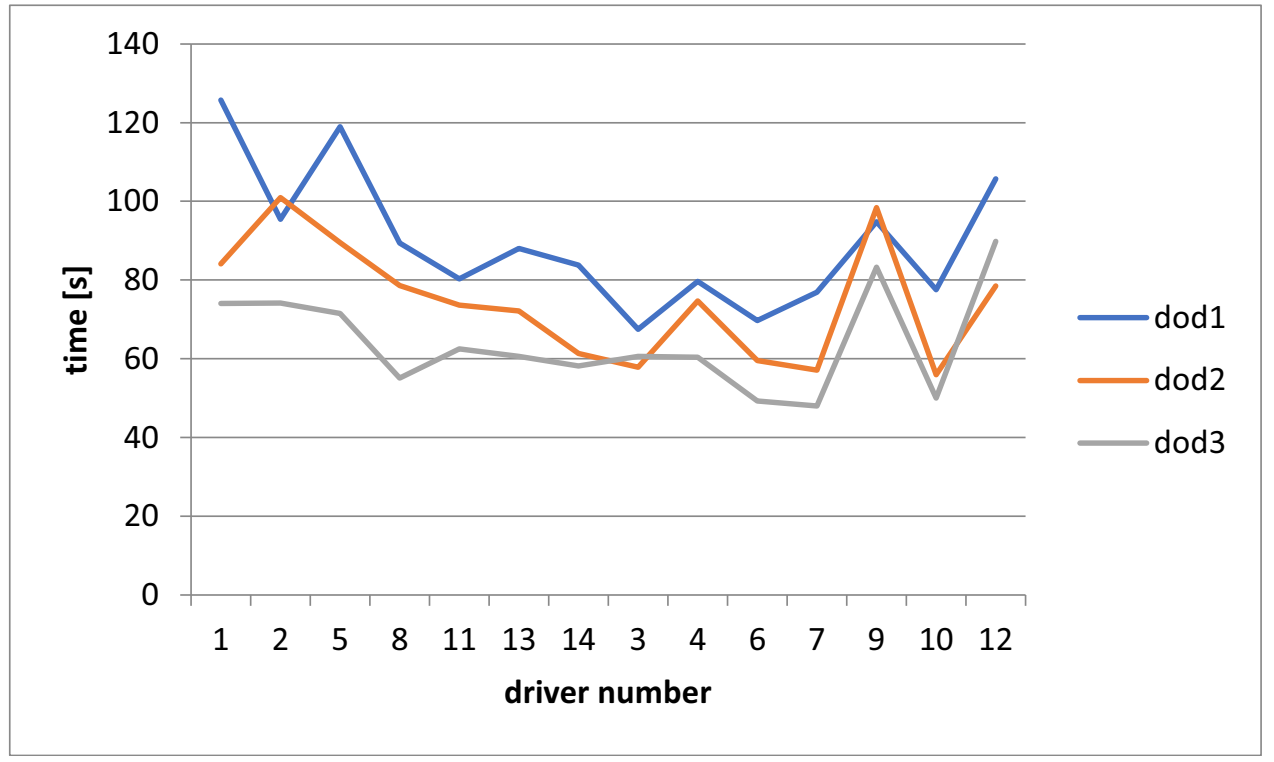

Fig. 2. Summary Test results on the second (dod1), fourth (dod2) and sixth (dod3) day of the morning and afternoon group experiment.

In Summary Tests from sample to sample the performance time is improved, all differences statistically significant at least $p<0.001$.

\section{Memory Test}

The results of the Memory Test are presented in Figure 3 and the test values for the dependent samples are listed in Table 4. 
Table 4. Summary results for the Memory Test

\begin{tabular}{|c|c|c|c|c|c|c|}
\hline $\begin{array}{c}\text { Correlation } \\
\text { between } \\
\text { measurements }\end{array}$ & $\begin{array}{c}\text { Average } \\
\text { time to } \\
\text { complete } \\
\text { the task }\end{array}$ & $\begin{array}{c}\text { Standard } \\
\text { deviation }\end{array}$ & $\begin{array}{c}\text { Number } \\
\text { of } \\
\text { drivers }\end{array}$ & $\begin{array}{c}T \\
\text { student } \\
\text { value }\end{array}$ & $\begin{array}{c}\text { Degree } \\
\text { of } \\
\text { freedom }\end{array}$ & $\begin{array}{c}p \text { - level of } \\
\text { significance }\end{array}$ \\
\hline 1 and 2 & 58.37000 & 12.02796 & 14 & 4.02088 & 13 & 0.001454 \\
\hline 1 and 3 & 49.65857 & 10.35056 & 14 & 4.97452 & 13 & 0.000254 \\
\hline 2 and 3 & 49.65857 & 10.35056 & 14 & 3.58296 & 13 & 0.003339 \\
\hline
\end{tabular}

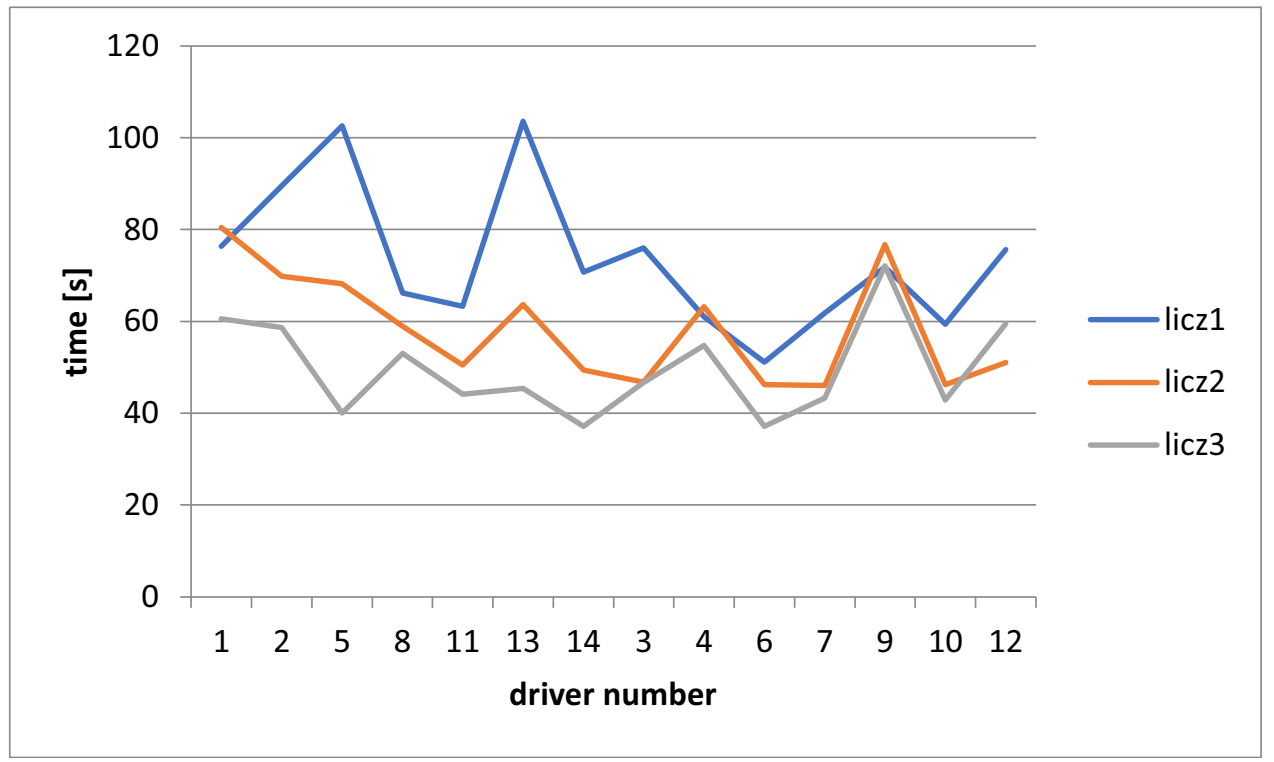

Fig. 3. Memory Test results on the second (licz1), fourth (licz2) and sixth (licz3) day of the morning and afternoon group experiment.

In the Memory Test, clear effect of the acquisition of practice can be seen. Any subsequent attempt brings significantly lower (better) execution times of test tasks.

\section{Test of letters substitution}

The results of the Test of letters substitution are presented in Figure 4 and the test values for the dependent samples are listed in Table 5.

In the Test of letters substitution, the differences in execution times between the various tests are statistically significant. 
Table 5. Summary of results for the Test of letters substitution

\begin{tabular}{|c|c|c|c|c|c|c|}
\hline $\begin{array}{c}\text { Correlation } \\
\text { between } \\
\text { measurements }\end{array}$ & $\begin{array}{c}\text { Average } \\
\text { time to } \\
\text { complete } \\
\text { the task }\end{array}$ & $\begin{array}{c}\text { Standard } \\
\text { deviation }\end{array}$ & $\begin{array}{c}\text { Number } \\
\text { of drivers }\end{array}$ & $\begin{array}{c}T \\
\text { student } \\
\text { value }\end{array}$ & $\begin{array}{c}\text { Degree of } \\
\text { freedom }\end{array}$ & $\begin{array}{c}p \text { - level of } \\
\text { significance }\end{array}$ \\
\hline 1 and 2 & 84.06000 & 14.50680 & 14 & 4.05902 & 13 & 0.001353 \\
\hline 1 and 3 & 75.16000 & 10.61157 & 14 & 7.63643 & 13 & 0.000004 \\
\hline 2 and 3 & 75.16000 & 10.61157 & 14 & 3.42972 & 13 & 0.004479 \\
\hline
\end{tabular}

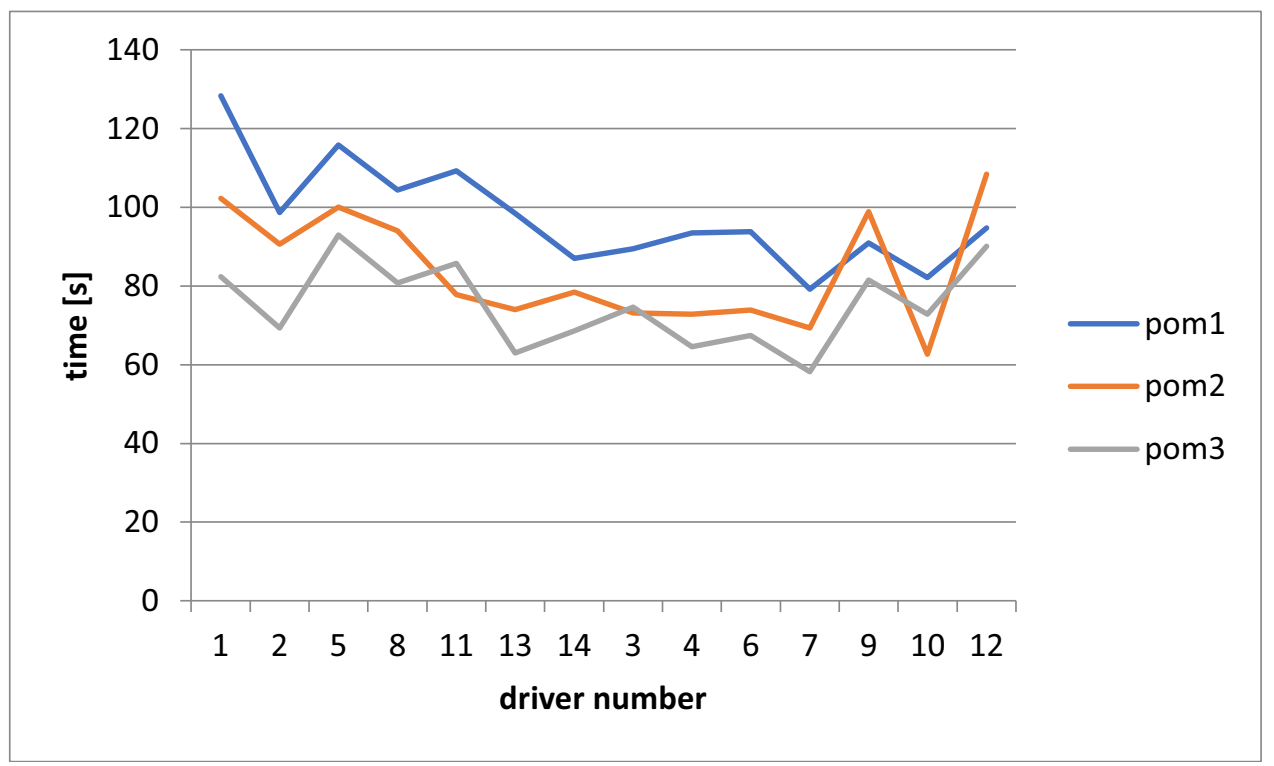

Fig. 4. Test of letters substitution results on the second (pom1), fourth (pom2) and sixth (pom3) day of the morning and afternoon group experiment.

\section{Conclusions}

The results from the individual measurements clearly show the ability to adapt to the task. The selection of professional predispositions enables the selection of persons of exceptional psychomotor efficiency, in a sense of protection the selected group of drivers against the burden of workplace specificity.

It should be remembered that the measurement of psychomotor efficiency is one of the components of a wider project exploring the influence of the external environment (including noise and noise) on the driver of the bus. Features such as personality can also play a significant role in the profession of bus driver [14].

While the health implications of the driver have a negative dimension, then in the cognitive dimension stimulation of the nervous system can be positive. At the same time, in all four tests there is an improvement in the "afternoon" group (the first seven drivers are in the morning group, the next seven are in the afternoon group). Although the differences 
between the two groups did not reach statistical significance but the shape of the curve suggests the influence of the time of day on the results, which requires verification.

\section{References}

1. P.S. Bruno, Q. R. Marcos, C. Amanda, Z. H. T. Paulo, Annoyance evaluation and the effect of noise on the health of bus drivers, Noise \& Health, September-October 2013, 15, 66, 301-6 (2013)

2. M. J. Griffin, Handbook of human vibration, Academic Press, London (1994)

3. T. M. Kiihlmann, Coping with occupational stress among urban bus and tram drivers. Journal of Occupational Psychology 63, 89-96, (1990)

4. E. Wągrowska-Koski, redakcja, Zagrożenia zdrowia kierowców pojazdów silnikowych związane ze szkodliwymi i uciążliwymi warunkami środowiska pracy, Instytut Medycyny Pracy im. prof. J. Nofera, Łódź (2007)

5. G. Aronsson, A. Rissler, Psychophysiological Stress Reactions in Female and Male Urban Bus Drivers Journal of Occupational Health Psychology 3, 2, 122-129, (1998)

6. pod red. D. Koradeckiej, Bezpieczeństwo pracy i ergonomia, tom 1 i 2, CIOP, Warszawa (1997)

7. H. Biglari, M. Hossein Ebrahimi, M. Salehi, M. Poursadeghiyan, I. Ahmadnezhad and M. Abbasi, Relationship between occupational stress and cardiovascular diseases risk factors in drivers. International Journal of Occupational Medicine and Environmental Health 29(6), 895-901, (2016)

8. E. Razmpa, K. Sadegh Niat, B. Saedi, Urban Bus Drivers' Sleep Problems and Crash Accidents, Indian J Otolaryngol Head Neck Surg 63(3), 269-273, (2011)

9. S. Hoseinabadi, S. Porabdeyan, M. Zare, S. Amiri, M. Ghasemi and A. Mansori, Does Traffic Stress Affect Distance Estimation and Recognition Accuracy in Urban Bus Drivers? Archives of Environmental \& Occupational Health 70, 214-217, (2013)

10. M. A. Machin, P. N. Hoare, The role of workload and driver coping styles in predicting bus drivers' need for recovery, positive and negative affect, and physical symptoms. Anxiety, Stress, \& Coping, October 2008; 21(4), 359-375, (2008)

11. U. Maheswari Krishnaswamy, M.S. Chhabria, A. Rao, Excessive sleepiness, sleep hygiene, and coping strategies among night bus drivers: A cross-sectional study, Indian Journal of Occupational and Environmental Medicine, (2017)

12. J. Boada-Grau, A. J. Prizmic-Kuzmica, M.D. González-Fernández and A. Vigil-Colet, Spanish version of Bus Drivers' Job Demands Scale (BDJD-24), Psicothema, 25, 2, 258 265, (2013)

13. Minister of Economy and Labor Ordinance of 5 August 2005 on occupational safety and health in work involving noise or mechanical vibration exposure. (in Polish - Dz. U. 2005,157 , pos. 1318)

14. S. Zivković, V. Nikolić and M. Markič, Influence of professional drivers' personality traits on road traffic safety: case study, International Journal of Injury Control and Safety, Promotion, 22, 2, 100-110, (2013) 